\title{
Studies on the Compatibility of Insecticides and Fungicides against Major Insect Pests and Diseases of Rice
}

\author{
Atanu Seni", Rini Pal and Bhima Sen Naik \\ Orissa University of Agriculture and Technology, AICRIP, RRTTS, Chiplima, \\ Sambalpur-768025, Odisha, India \\ *Corresponding author
}

\section{A B S T R A C T}

The present experiment was carried out in the experimental farm of Regional Research and Technology Transfer Station (OUAT), Chiplima, Sambalpur, Odisha, during kharif 2013 and Rabi 2013-14 to determine the compatibility of selected insecticides and fungicides

\section{Keywords}

Combination, Compatibility, DH, WEH, Hoppers, Blast, Sheath blight, Phytotoxicity.

Article Info

Accepted:

10 September 2017

Available Online:

10 October 2017 against major insect pests like stem borer, brown plant hopper and diseases like blast and sheath blight of rice. The treatments include: T1- Flubendiamide (4\%) + Buprofezin (20\%) 24 SC @875 ml/ha; T2- Triazophos 40 EC @ 750 ml/ha; T3- Hexaconazole 5 SC @ 1000 ml/ha; T4- Tricyclazole 75 WP @ 300 g/ha; T5- T1+T3; T6- T1+T4; T7- T2+T3; T8T2+T4; T9-untreated control. Among the different combinations tested, Flubendiamide $(4 \%)+$ Buprofezin (20\%) 24 SC in combination with Hexaconazole 5 SC recorded less dead heart $(2.22 \%)$ and white ear head $(2.94 \%)$, blast incidence $(2.76 \%)$, sheath blight incidence $(3.55 \%)$ and produced highest yield $(4.3 \mathrm{t} / \mathrm{ha})$ followed by Flubendiamide $(4 \%)$ + Buprofezin (20\%) SC $(2.63 \%, 3.75 \%, 3.43 \%, 4.90 \%$ and 4 t/ha) and Flubendiamide $(4 \%)+$ Buprofezin (20\%) 24 SC in combination with Tricyclazole 75 WP (4\%, 1.23\%, $1.61 \%, 4.05 \%$ and $3.8 \mathrm{t} / \mathrm{ha}$ ) compared to untreated control where the incidence of DH $(11.70 \%)$, WEH (12\%), blast incidence $(4.60 \%)$, sheath blight incidence was $5.7 \%$ and produced yield $(2.4 \mathrm{t} / \mathrm{ha})$. There was no reduction in the efficacy of these insecticides and fungicides when used as tank mix. No phytotoxicity symptoms were noticed in treated field. So, all the insecticides and fungicides combinations are compatible with each other and can be safely used as tank mix for the control of rice insect pests and diseases, thus, saving labour costs.

\section{Introduction}

Rice (Oryza sativa L.) is the staple food of more than three billion people in the world and fulfills the nutritional requirement of half of the world population (FAO, 2004). In India it is the most important cereal crop covering about one-fourth of the total cropped area and providing food to about half of the Indian population. There are about 10,000 varieties of rice are grown in the world out of which almost 4,000 are grown in India (Kulmitra et al., 2017). Introduction and wide adoption of high yielding varieties has led to severe incidence of different insect pests. But, its production is hampers by infestation of a large number of insect pests and pathogens. Among them, yellow stem borer (YSB), Scirpophaga incerulas (Walk.), brown plant hopper (BPH), Nilaparvata lugens (Stål), Rice blast caused by Pyricularia oryzae Cavara and Sheath blight caused by 
Rhizoctonia solani Kunh are the major entities for huge economic crop losses of rice. The YSB attacks the crop from the seedling stage to the harvesting stage and thus causes complete loss of affected tillers. Dead hearts are produced when the insect attacks at vegetative stage while white heads occur when the stem borer attack at time of heading. Yield losses due to yellow stem borer are estimated $1-19 \%$ in early planted and $38-80 \%$ in late transplanted rice crops (Catinding and Heong, 2003). BPH attacks the crop from late vegetative stage to grains hardening stage. Both the nymphs and adults suck the sap from the plant causing chlorotic, wilting and drying up of rice plant. This feeding damage is commonly known as 'hopper-burn' which begins in patches but spread rapidly as the hoppers move from dying plants to adjacent plants.

They causes almost 10 to 90 percent yield losses in rice but if timely control measures are not taken up, there may be possibilty of total crop loss within a very short period (Seni and Naik, 2017). Rice blast caused by Pyricularia oryzae Cavara is one of the most destructive and wide spread diseases of rice (Jia et al., 2000). In severe cases, it may causes up to $80 \%$ of total yield reduction. Sheath blight, caused by Rhizoctonia solani Kunh, is an another important destructive disease of rice occurs in all rice growing areas of the world (Teng et al., 1990). Depending upon the age of the plant, time of infection and severity, it causes yield loss to the extent of 5.9 to 69 per cent (Swamy et al., 2009). Most of the times insect pests and diseases occurs together in rice. In such conditions use of combination of suitable insecticides and fungicides is economical and practicable for their management. Keeping this in mind, the study was undertaken to evaluate the compatibility of selected insecticides and fungicides against major insect pests and diseases of rice under field condition.

\section{Materials and Methods}

The experiment was conducted in the experimental farm of Regional Research and Technology Transfer Station (OUAT), Chiplima, Sambalpur, Odisha, during kharif 2013 and Rabi 2013-14 in Randomized Block Design (RBD), having 9 treatments which were replicated thrice in a net experimental area of $5 \mathrm{~m} \mathrm{x} 4 \mathrm{~m}$ each. The Station is situated at $20^{\circ} 21^{\prime} \mathrm{N}$ latitude and $80^{\circ} 55^{\prime} \mathrm{E}$ longitude in Dhankauda block of Sambalpur district at an altitude of $178.8 \mathrm{~m}$ above MSL. The climate of the area is warm/sub humid. The cultivar Jaya was transplanted at 25 days old at $20 \mathrm{~cm}$ $\mathrm{x} 15 \mathrm{~cm}$ hill spacing.

All the agronomic practices were followed during crop growth period. The treatments were: T1- Flubendiamide (4\%) + Buprofezin (20\%) 24 SC @ 875 ml/ha; T2- Triazophos 40 EC @750 ml/ha; T3- Hexaconazole 5 SC @ $1000 \mathrm{ml} / \mathrm{ha} ; \mathrm{T} 4-$ Tricyclazole $75 \mathrm{WP}$ @ 300 g/ha; T5- T1+T3; T6- T1+T4; T7T2+T3; T8-T2+T4; T9-untreated control. Applications of all the treatments were done at 20, 45 and 65 DAT except untreated control. The insecticides were applied as high volume sprays @ 500 litres of spray fluid/ha. Observations on the incidence of dead heart (DH) were taken on 10 randomly selected hills per plot from each replication at 55 and 75 days after transplanting. The white ear head (WEH) was counted on 10 randomly selected hills from each plot just before harvest. Then percentage of dead hearts/ white ears was worked out. The hopper population per 10 hills was recorded 7 days after third spray. Percentage disease incidence of blast and sheath blight was recorded 10 days after third application of treatments. Symptoms of phytotoxicity were also recorded at 5 and 10 days after application of treatments. The Mean value of data obtained from field experiments were analyzed statistically by ANOVA. Finally the grain 
yield was recorded in plot basis and expressed in ton/ ha.

\section{Results and Discussion}

\section{Stem borer management}

The result showed that all the treatments were significantly effective in reducing the infestation of rice yellow stem borer (YSB) and thus, reducing the formation of dead heart and white ear significantly as compared to the control (Tables 1 and 2). Among the different combinations tested, Flubendiamide $(4 \%)+$ Buprofezin (20\%) $24 \mathrm{SC}$ in combination with Hexaconazole 5 SC recorded less dead heart $(2.22 \%)$ and white ear head $(2.94 \%)$, followed by Flubendiamide $4 \%+$ Buprofezin 20 SC $(2.63 \%, 3.75 \%)$ and Flubendiamide $4 \%+$ Buprofezin $20 \mathrm{SC}$ in combination with Tricyclazole 75 WP $(4 \%, 1.23 \%)$ compared to untreated control where the incidence of $\mathrm{DH}$ (11.70\%), WEH (12\%). The present finding in agreement with the Kartikeyan et al., (2012) and they observed that flubendiamide + buprofezin treated plots had significantly less DH, WEH and hoppers than other treated plots. Tohnishi et al., (2005), mentioned the strong insecticidal property of flubendiamide 480 SC against lepidopteran insect pests including resistant strains and it also shows safety for non-target organism. Flubendiamide $20 \mathrm{WDG}$ at 12.5, 25 and $50 \mathrm{~g}$ a.i/ ha was found effective in reducing the stem borer damage at all the doses tested and was found to be safe to the natural enemies in the rice ecosystem (Gowda and Naik, 2005). Gowda (2005) reported that flubendiamide 20 WDG at 25 and $50 \mathrm{~g}$ a.i/ ha recorded low incidence of dead hearts (0.81 and $0.53 \%)$ and white ears (1.26 and $1.20 \%$ ) compared to other treatments.

\section{Hoppers management}

Brown plant hopper $(\mathrm{BPH})$ is another major insect pest infesting rice in Hirakud command area, chiplima. From the experimental result (Tables 1 and 2), it is observed that the best treatment was T5- Flubendiamide (4\%) + Buprofezin (20\%) 24 SC @ $875 \mathrm{ml} / \mathrm{ha}$ in combination with Hexaconazole 5 SC @ 1000 $\mathrm{ml} /$ ha which recorded 18 numbers of BPH per 10 hills followed by Flubendiamide $(4 \%)+$ Buprofezin (20\%) 24 SC @ $875 \mathrm{mlha}^{-1}$ in combination with Tricyclazole 75 WP @ 300 $\mathrm{g} / \mathrm{ha} \quad(24.5$ numbers/10 hills) and Flubendiamide 4\% + Buprofezin 20 SC @ 875 mlha $^{-1}$ (25.5 numbers/10 hills). T1, T5, T6 treatments were superior in hopper management than T2, T3, T4, T7 and T8 treatments and differed significantly from untreated control plot (82 numbers/10 hills). Kartikeyan et al., (2012) also observed the effectiveness of combination product flubendiamide $(4 \%)+$ buprofezin $(20 \%) 24$ SC @ (875 ml/ha) for suppression of plant hoppers population in rice.

\section{Effect on blast and sheath blight}

The Field experiment revealed that in both the crop seasons blast and sheath blight disease incidence was lower in Jaya cultivar and among the treatments, Flubendiamide $(4 \%)+$ Buprofezin (20\%) 24 SC @ $875 \mathrm{ml} / \mathrm{ha}$ in combination with Tricyclazole 75 WP @ 300 $\mathrm{g} /$ ha recorded lowest blast incidence $(1.61 \%)$ whereas Flubendiamide 4\% + Buprofezin 20 $\mathrm{SC} @ 875 \mathrm{ml} / \mathrm{ha}$ in combination with Hexaconazole 5 SC @ 1000 ml/ha treated plots had lowest sheath blight incidence $(3.55 \%)$ (Tables 3). There was a significant difference among the combined treatments with respect to disease incidence of blast and sheath blight diseases and all treatments recorded significantly lower disease incidence compared to untreated control in both the seasons. Swamy et al., 2009 observed the effectiveness of Hexaconazole 5 SC @ 2 ml/l for sheath blight management (controlled the disease to the tune of 31 per cent). Prasad et al., 2015 found that the combination of Flubendiamide + buprofezin 24 SC @ 1.75 
ml/1 and Tricyclazole 75 WP @ $0.6 \mathrm{~g} / \mathrm{l}$ was most effective against both stem borer and leaf blast with 3.22 and $5.01 \%$ infestation, respectively and fetched average grain yield of $30.39 \mathrm{q} / \mathrm{ha}$.

\section{Phytotoxicity effect}

As regards to the crop health by visual observation it is observed that no phytotoxic symptoms viz., leaf yellowing, tip necrosis, scorching, epinasty and hyponasty were recorded 5 and 10 days after application of each treatments in both the seasons.

\section{Yield}

It is found that in table 4, Flubendiamide 4\% + Buprofezin 20 SC @ $875 \mathrm{ml} / \mathrm{ha}$ in combination with Hexaconazole 5 SC @ 1000 $\mathrm{ml} / \mathrm{ha}$ treated plot recorded highest yield of $4.3 \mathrm{t} / \mathrm{ha}$ (44\% yield increase over control) followed by Flubendiamide 4\% + Buprofezin 20 SC@ $875 \mathrm{ml} / \mathrm{ha}(4 \mathrm{t} / \mathrm{ha}$ and $40 \%$ yield increase over control),

Flubendiamide 4\% + Buprofezin 20 SC @ $875 \mathrm{ml} / \mathrm{ha}$ in combination with Tricyclazole 75 WP @ $300 \mathrm{~g} / \mathrm{ha}(3.85 \mathrm{t} / \mathrm{ha})$, Triazophos 40EC@750 ml/ha in combination with Tricyclazole 75 WP @ $300 \mathrm{~g} / \mathrm{ha}(3.71 \mathrm{t} / \mathrm{ha})$, Triazophos 40EC @ $750 \mathrm{ml} / \mathrm{ha}(3.54 \mathrm{t} / \mathrm{ha})$,

Triazophos $40 \quad$ EC @ $9750 \quad \mathrm{ml} / \mathrm{ha}$ in combination with Hexaconazole 5 SC @ 1000 $\mathrm{ml} / \mathrm{ha}$ (3.35 t/ha), Hexaconazole 5 SC @ 1000 $\mathrm{ml} / \mathrm{ha}$ (3.28 t/ha), Tricyclazole 75 WP @ 300 $\mathrm{g} / \mathrm{ha}(3.26 \mathrm{t} / \mathrm{ha})$ respectively.

Table.1 Efficacy of chemicals against major insect pests of rice in Kharif, 2013

\begin{tabular}{|c|c|c|c|c|c|c|}
\hline \multirow{2}{*}{$\begin{array}{l}\text { T. } \\
\text { No }\end{array}$} & \multirow[t]{2}{*}{ Treatment } & \multirow{2}{*}{$\begin{array}{l}\text { Dose (g or } \\
\text { ml/ha) }\end{array}$} & \multicolumn{2}{|c|}{ Stem borer (\% DH) } & \multirow{2}{*}{$\begin{array}{c}\text { WEH } \\
(\%)\end{array}$} & \multirow{2}{*}{$\begin{array}{c}\begin{array}{c}\text { No. Plant } \\
\text { hoppers/10 hills }\end{array} \\
72 \text { DAT }\end{array}$} \\
\hline & & & 55 DAT* & 75 DAT & & \\
\hline $\mathrm{T}_{1}$ & $\begin{array}{l}\text { Flubendiamide } 4 \%+ \\
\text { Buprofezin } 20 \mathrm{SC}\end{array}$ & 875 & $4.61(2.24)$ & $\begin{array}{c}1.84 \\
(1.52)\end{array}$ & $\begin{array}{c}4.48 \\
(2.23)\end{array}$ & 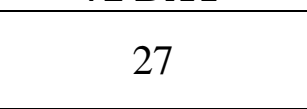 \\
\hline $\mathrm{T}_{2}$ & Triazophos 40EC & 750 & $5.51(2.44)$ & $\begin{array}{c}2.74 \\
(1.79)\end{array}$ & $\begin{array}{c}5.56 \\
(2.45)\end{array}$ & 41 \\
\hline $\mathrm{T}_{3}$ & Hexaconazole 5 SC & 1000 & $8.06(2.92)$ & $\begin{array}{c}10.11(3.2 \\
6)\end{array}$ & $\begin{array}{c}9.03 \\
(3.08)\end{array}$ & 65 \\
\hline $\mathrm{T}_{4}$ & Tricyclazole $75 \mathrm{WP}$ & 300 & $7.33(2.79)$ & $\begin{array}{c}8.37 \\
(2.98) \\
\end{array}$ & $\begin{array}{c}7.75 \\
(2.85) \\
\end{array}$ & 67 \\
\hline $\mathrm{T}_{5}$ & $\mathrm{~T} 1+\mathrm{T} 3$ & $875+1000$ & $3.74(2.06)$ & $\begin{array}{c}1.68 \\
(1.47)\end{array}$ & $\begin{array}{c}3.71 \\
(1.05)\end{array}$ & 21 \\
\hline $\mathrm{T}_{6}$ & $\mathrm{~T} 1+\mathrm{T} 4$ & $875+300$ & $4.37(2.20)$ & $\begin{array}{c}1.90 \\
(1.54)\end{array}$ & $\begin{array}{c}4.10 \\
(2.14)\end{array}$ & 24 \\
\hline $\mathrm{T}_{7}$ & $\mathrm{~T} 2+\mathrm{T} 3$ & $750+1000$ & $6.02(2.54)$ & $\begin{array}{c}4.83 \\
(2.30)\end{array}$ & $\begin{array}{c}8.96 \\
(3.07)\end{array}$ & 36 \\
\hline $\mathrm{T}_{8}$ & $\mathrm{~T} 2+\mathrm{T} 4$ & $750+300$ & $5.13(2.70)$ & $\begin{array}{c}3.82 \\
(2.07)\end{array}$ & $\begin{array}{c}4.57 \\
(2.25)\end{array}$ & 39 \\
\hline $\mathrm{T}_{9}$ & Untreated control & - & $\begin{array}{l}10.41 \\
(3.29) \\
\end{array}$ & $\begin{array}{l}14.38 \\
(3.85) \\
\end{array}$ & $\begin{array}{l}12.86 \\
(3.65) \\
\end{array}$ & 88 \\
\hline & S.Em & & 0.17 & 0.09 & 0.12 & 1.97 \\
\hline & $\mathrm{CD}(5 \%)$ & & 0.53 & 0.28 & 0.35 & 5.91 \\
\hline
\end{tabular}

*DAT: Days after Transplanting, Figures in parentheses are square root transformed values 
Table.2 Efficacy of chemicals against major insect pests of rice in Rabi, 2013-14

\begin{tabular}{|c|c|c|c|c|c|c|}
\hline \multirow{2}{*}{$\begin{array}{l}\text { T. } \\
\text { No }\end{array}$} & \multirow[t]{2}{*}{ Treatment } & \multirow{2}{*}{$\begin{array}{c}\text { Dose (g or } \\
\mathrm{ml} / \mathrm{ha})\end{array}$} & \multicolumn{2}{|c|}{ Stem borer (\% DH) } & \multirow{2}{*}{$\begin{array}{c}\text { WEH } \\
(\%)\end{array}$} & \multirow{2}{*}{$\begin{array}{c}\begin{array}{c}\text { No. Plant } \\
\text { hoppers/10 } \\
\text { hills }\end{array} \\
72 \text { DAT }\end{array}$} \\
\hline & & & 55 DAT & 75 DAT & & \\
\hline $\mathrm{T}_{1}$ & $\begin{array}{l}\text { Flubendiamide } 4 \%+ \\
\text { Buprofezin } 20 \mathrm{SC}\end{array}$ & 150 & $\begin{array}{c}2.59 \\
(1.75)\end{array}$ & $\begin{array}{c}1.52 \\
(1.42)\end{array}$ & $\begin{array}{c}3.02 \\
(1.84)\end{array}$ & 24 \\
\hline $\mathrm{T}_{2}$ & Triazophos 40EC & 200 & $\begin{array}{l}4.73 \\
(2.27)\end{array}$ & $\begin{array}{c}2.68 \\
(1.78)\end{array}$ & $\begin{array}{l}4.88 \\
(2.30)\end{array}$ & 37 \\
\hline $\mathrm{T}_{3}$ & Hexaconazole $5 \mathrm{SC}$ & 1000 & $\begin{array}{l}7.25 \\
(2.78)\end{array}$ & $\begin{array}{c}9.07 \\
(3.09)\end{array}$ & $\begin{array}{c}8.16 \\
(2.94)\end{array}$ & 62 \\
\hline $\mathrm{T}_{4}$ & Tricyclazole $75 \mathrm{WP}$ & 1250 & $\begin{array}{l}7.56 \\
(2.84)\end{array}$ & $\begin{array}{c}9.62 \\
(3.18)\end{array}$ & $\begin{array}{c}8.72 \\
(3.03)\end{array}$ & 59 \\
\hline $\mathrm{T}_{5}$ & $\mathrm{~T} 1+\mathrm{T} 3$ & $150+1000$ & $\begin{array}{c}2.40 \\
(1.70)\end{array}$ & $\begin{array}{l}1.06 \\
(1.24)\end{array}$ & $\begin{array}{c}2.17 \\
(1.63)\end{array}$ & 15 \\
\hline $\mathrm{T}_{6}$ & $\mathrm{~T} 1+\mathrm{T} 4$ & $150+1250$ & $\begin{array}{c}3.53 \\
(1.99)\end{array}$ & $\begin{array}{c}2.39 \\
(1.69)\end{array}$ & $\begin{array}{c}3.90 \\
(2.08)\end{array}$ & 25 \\
\hline $\mathrm{T}_{7}$ & $\mathrm{~T} 2+\mathrm{T} 3$ & $200+1000$ & $\begin{array}{c}3.88 \\
(2.07)\end{array}$ & $\begin{array}{c}3.34 \\
(1.95)\end{array}$ & $\begin{array}{c}4.13 \\
(2.14)\end{array}$ & 37 \\
\hline $\mathrm{T}_{8}$ & $\mathrm{~T} 2+\mathrm{T} 4$ & $200+1250$ & $\begin{array}{c}5.17 \\
(2.37)\end{array}$ & $\begin{array}{l}4.09 \\
(2.14)\end{array}$ & $\begin{array}{c}4.69 \\
(2.27)\end{array}$ & 30 \\
\hline $\mathrm{T}_{9}$ & Untreated control & - & $\begin{array}{c}8.95 \\
(3.07)\end{array}$ & $\begin{array}{l}13.06 \\
(3.68)\end{array}$ & $\begin{array}{l}11.22 \\
(3.41)\end{array}$ & 76 \\
\hline & S.Em & & 0.14 & 0.16 & 0.10 & 2.54 \\
\hline & CD $(5 \%)$ & & 0.43 & 0.48 & 0.32 & 7.62 \\
\hline
\end{tabular}

*DAT: Days after Transplanting, Figures in parentheses are square root transformed values

Table.3 Effect of chemicals on the blast and sheath blight incidence of rice

\begin{tabular}{|l|l|c|c|c|c|}
\hline \multirow{2}{*}{$\begin{array}{l}\text { T. } \\
\text { No. }\end{array}$} & Treatment & \multicolumn{2}{|c|}{ Blast incidence (\%) } & \multicolumn{2}{c|}{ Sheath blight incidence (\%) } \\
\cline { 3 - 6 } & & Kh'13 & \multicolumn{1}{c|}{ Rabi'13-14 } & \multicolumn{1}{|c|}{ Kh'13 } & Rabi'13-14 \\
\hline 1 & $\begin{array}{l}\text { Flubendiamide 4\% } \\
\text { Buprofezin 20 SC }\end{array}$ & $3.70(2.05)$ & $3.17(1.91)$ & $5.4(2.44)$ & $4.4(2.21)$ \\
\hline 2 & Triazophos 40EC & $4.65(2.27)$ & $3.67(2.04)$ & $5.6(2.47)$ & $4.8(2.29)$ \\
\hline 3 & Hexaconazole 5 SC & $2.47(1.72)$ & $2.47(1.72)$ & $4.0(2.11)$ & $3.4(1.97)$ \\
\hline 4 & Tricyclazole 75 WP & $0.88(1.16)$ & $0.75(1.11)$ & $5.1(2.36)$ & $4.0(2.13)$ \\
\hline 5 & T1+T3 & $3.13(1.91)$ & $2.40(1.70)$ & $3.9(2.10)$ & $3.2(1.91)$ \\
\hline 6 & T1+T4 & $1.45(1.39)$ & $1.78(1.51)$ & $4.4(2.21)$ & $3.7(2.04)$ \\
\hline 7 & T2+T3 & $3.62(2.03)$ & $2.98(1.87)$ & $4.2(2.16)$ & $3.6(2.03)$ \\
\hline 8 & T2+T4 & $1.56(1.43)$ & $1.72(1.49)$ & $4.9(2.32)$ & $4.1(2.14)$ \\
\hline 9 & Untreated control & $4.73(2.29)$ & $4.48(2.23)$ & $6.3(2.61)$ & $5.1(2.37)$ \\
\hline & S.Em & 0.06 & 0.04 & 0.04 & 0.03 \\
\hline & CD $(5 \%)$ & 0.19 & 0.11 & 0.12 & 0.10 \\
\hline
\end{tabular}

Figures in parentheses are square root transformed values 
Table.4 Effect of certain chemicals on grain yield of rice

\begin{tabular}{|c|c|c|c|c|c|}
\hline \multirow[t]{2}{*}{ T. No. } & \multirow[t]{2}{*}{ Treatments } & \multicolumn{2}{|c|}{ Grain yield (t/ha) } & \multirow[t]{2}{*}{ Mean } & \multirow{2}{*}{$\begin{array}{c}\text { (\%) yield } \\
\text { increase over } \\
\text { control }\end{array}$} \\
\hline & & $\begin{array}{l}\text { Kharif, } \\
2013\end{array}$ & Rabi, 2013-14 & & \\
\hline 1 & $\begin{array}{l}\text { Flubendiamide } 4 \%+ \\
\text { Buprofezin } 20 \mathrm{SC}\end{array}$ & 3.77 & 4.25 & 4.01 & 40 \\
\hline 2 & Triazophos 40EC & 3.21 & 3.86 & 3.54 & 31 \\
\hline 3 & Hexaconazole $5 \mathrm{SC}$ & 3.00 & 3.55 & 3.28 & 26 \\
\hline 4 & Tricyclazole $75 \mathrm{WP}$ & 3.06 & 3.45 & 3.26 & 25 \\
\hline 5 & $\mathrm{~T} 1+\mathrm{T} 3$ & 3.99 & 4.60 & 4.30 & 44 \\
\hline 6 & $\mathrm{~T} 1+\mathrm{T} 4$ & 3.87 & 3.82 & 3.85 & 37 \\
\hline 7 & $\mathrm{~T} 2+\mathrm{T} 3$ & 3.12 & 3.57 & 3.35 & 28 \\
\hline 8 & $\mathrm{~T} 2+\mathrm{T} 4$ & 3.43 & 3.98 & 3.71 & 35 \\
\hline 9 & Untreated control & 2.13 & 2.72 & 2.43 & - \\
\hline & S.Em & 0.11 & 0.07 & & \\
\hline & $\mathrm{CD}(5 \%)$ & 032 & 023 & & \\
\hline
\end{tabular}

All The treatments given plots gave superior yield than untreated control plot. The present findings are in agreement with the findings of Bhuvaneshwari and Krishnam Raju (2013) who reported that the effectiveness of six insecticides viz., buprofezin, pymeterozine, acephate, chlorantraniliprole, dinotefuron, and imidacloprid + ethiprole did not in any way hamper by mixing with different fungicides and they are compatible with each other for spray application to control the insect pests viz., stem borer, brown plant hopper, leaf folder and sheath blight. Bhatnagar, 2004 reported that the combination of cartap (Padan $50 \mathrm{WP}$ ) and tricyclazole (Beam 75 WP) was effective in reducing the damage by rice leaf folder and blast, and found to be compatible. Singh et al., 2010 found that combination treatments of fungicides (tricyclazole and iprobenphos) and insecticides (indoxacarb and cartap hydrochloride) were biologically as effective as their individual treatments against neck blast, leaf folder and stem borer of rice.

Thus, the present study revealed that tank mixing of insecticides with fungicides involved in the present experiments did not reduce the efficacy of the insecticides and fungicides against stem borer, hopper, rice blast and sheath blight. All the treatments with insecticide-fungicide combinations had significantly higher grain yield as compared to the control. Hence, they are compatible with each other for spray application to control the rice pests and may be recommended for field use.

\section{Acknowledgement}

The authors are highly thankful to ICARIndian Institute of Rice Research, Rajendranagar, Hyderabad and Orissa University of Agriculture and Technology, Bhubaneswar for financial assistance.

\section{References}

Bhatnagar, A., 2004. Compatibility of pesticides against rice leaf folder and blast. Annals of Plant Protection Sciences. 12 (1): 208-210.

Bhuvaneshwari, V., Krishnam, Raju, S., 2013. Compatibility of fungicides and insecticides targeting sheath blight and major rice pests. Journal of Rice 
Research. 6 (2): 64-71.

Catinding, J. L. A., Heong, H. L. 2003. Rice Doctor@2003, IRRI, Phillipines pp1-10.

Food and Agricultural Organization of the United Nations, 2004. The state of food security in the world, FAO, Rome, Italy, 30-31.

Gowda, J., 2005. Bio efficacy of flubendiamide 20 WDG (RIL- 038) against rice stemborer, Scirpophaga incertulas (Wlk). Pestology. 29: 19-20.

Gowda, J., and Naik, K., 2005. Bioefficacy of flubendiamide 20 WDG (RIL-038) against paddy pests and their natural enemies. Pestology. 29: 58-60.

Jia, Y., Me Adams, S. A., Bryan, G. T., Hershay, H. P., Valent, B., 2000. Direct interaction of resistance genes products confers riceblast resistance. The Embo Journal. 19: 4004-4014.

Kartikeyan, K., Purushothaman, S. M., Smitha, S. G., Ajish, P. G., 2012. Efficacy of new insecticide combination against major pests of paddy. Indian Journal of Plant Protection 40 (4): 276279.

Kulmitra, A. K., Sahu, N., Sahu, M. K., Kumar, R., Kushram, T., Sanath Kumar, V. B., 2017. Growth of Rice Blast Fungus Pyricularia oryzae (Cav.) on Different Solid and Liquid Media. International Journal of Current Microbiology and Applied Sciences. 6 (6): 1154-1160.

Ling, K. C., 1977. Rice ragged stunt disease. International Rice Research Newsletter. 5: 6-7.

Prasad, S. S., Gupta, P. K., Mishra, J. P.,
2015. Field studies on compatibility of new insecticides and fungicides against stem borer and leaf blast under semi deep water rice condition. International Journal of Research and Reviews. 2 (12): 723-726.

Seni, A., Naik, B. S., 2017. Evaluation of some insecticides against Brown Plant Hopper, Nilaparvata lugens (Stal) in Rice, Oryza sativa L. International Journal of Bio-resource and Stress Management. 8 (2): 268-271.

Singh, R., Sunder, S., Dodan, D. S., Ram, L., Singh. R., 2010. Evaluation of scented rice genotype $\mathrm{s}$ and fungicides against blast and compatibility of pesticides used against neck blast, stem borer and leaf folder. Indian Phytopathology. 63 (2): 212-215.

Swamy, H. N., Sannaulla, S., Kumar, M. D., 2009. Screening of new fungicides against rice sheath blight disease. Karnataka Journal of Agricultural Sciences. 22 (2): 448-449.

Teng, P. S., Torries, C. Q., Nuque, F. L., Calvero, S. B., 1990. Current knowledge on crop losses in tropical rice. In: IRRI (ed) crop loss assessment in rice. International Rice Research Institute, Los Banos. Pp 39- 54.

Tohnishi, M., Nakao, H., Furuya, T., Seo, A., Kodama, H., Tsubata, K., Fujioka, S., Hirooka, T. and Nishimatsu, 2005. Flubendiamide, a novel insecticide highly active against lepidopterous insect pests. Journal of Pesticide Science. 30: 354-360.

\section{How to cite this article:}

Atanu Seni, Rini Pal and Bhima Sen Naik. 2017. Studies on the Compatibility of Insecticides and Fungicides against Major Insect Pests and Diseases of Rice. Int.J.Curr.Microbiol.App.Sci. 6(10): 930-936. doi: https://doi.org/10.20546/ijcmas.2017.610.111 